ORIGINAL PAPER

\title{
Fungal Infections in Major Burns - 2 Years Overview
}

Andra Luana LAZARESCU ${ }^{1}$, Andreea GROSU-BULARDA ${ }^{\top}$, Mihaela-Cristina ANDREI ${ }^{1}$, Sabina GRAMA ${ }^{\top}$, Adrian FRUNZA ${ }^{1,2}$, Dan Aurel IONESCU', Serban ARGHIR POPESCU1,2, Tiberiu Paul NEAGU11,2, Ioan LASCAR ${ }^{1,2}$

\begin{abstract}
Infections are the most severe and the most frequent complication in major burns requiring adequate diagnosis and treatment. Extensive burned areas, impaired immune system and antibiotic therapy contribute to the development of opportunistic fungal infections. An important aspect is the increased level of antimicrobial resistance in our country. We present a two years study on the burn patients hospitalized in our institution. A total of 355 burned patients were hospitalized during this period, 210 (59\%) of them being addmited in Critical Care Burn Unit. We noted the main infectious complications and established a dinamic microbian mapping during patient hospitalization. Fungal infections were noted. We performed microbiological screening: testing at admission and once a week or in case of clinical signs from all potential sites. For the clinical therapy of mycoses, it is mandatory to know whether a fungal colonization or a fungal infection is involved. Unfortunately, often in severe burned patients, clinical presentation is unspecific and sensitivity of diagnostic results may be unreliable. Invasive fungal infections due to Candida species and Aspergillus species are important emerging causes of morbidity and mortality. The systemic use of antifungal agents is conducted depending on the general condition of the burn patient, the fungal species involved and the confirmation of fungemia. In conclusion, specific treatment of infectious complications has to be conducted according to the characteristics of the patients in order to reduce morbidity and mortality and avoid the development of antimicrobial resistance.
\end{abstract}

Keywords: major burns, complications, fungal infections, risk factors.

\section{Rezumat}

Infecțiile sunt cele mai severe și frecvente complicații la marii arși, necesitând diagnostic și tratament adecvat. Suprafața arsă extensivă, un sistem imun deficitar și terapia antibiotică contribuie la dezvoltarea infecțiilor fungice oportuniste. Un aspect de luat în seamă este rezistența microbiană crescută în țara noastră. Prezentăm un studiu desfăşurat pe o perioadă de doi ani a pacienților cu arsuri severe spitalizați în unitatea noastră. Un număr de 355 de pacienți arși au fost internați în această perioadă, 210 (59\%) dintre aceștia fiind admiși în Unitatea de Îngrijire a Arşilor Grav. Am observat că cea mai importantă complicație este reprezentată de infecții, și am realizat o hartă a rezistenței microbiene a fiecărui pacient în parte. Infecțiile fungice au fost notate. Am efectuat screening-ul antimicrobian: la internare, apoi o dată pe săptămână și ori de câte ori au existat focare infecțioase. În privința terapiei clinice a micozelor, este obligatoriu de disociat prezența unei colonizări fungice sau a unei infecții fungice. Din nefericire, adesea în cazul pacienților arși, prezența semnelor clinice este nespecifică și sensibilitatea rezultatelor diagnostice este inconstantă. Infecțiile fungice invazive provocate de Candida spp și Aspergillus spp reprezintă cauze

${ }^{1}$ Clinic of Plastic Surgery, Aesthetic and Reconstructive Microsurgery, Clinical Emergency Hospital, Bucharest, Romania 2 "Carol Davila" University of Medicine and Pharmacy, Bucharest, Romania

\section{Corresponding author.}

Andreea GROSU-BULARDA, Clinical Emergency Hospital, $8^{\text {th }}$

Floreasca Avenue, Bucharest, Romania.

E-mail: andreeabularda@gmail.com 
importante și rapide de morbiditate și mortalitate. Uzul sistemic al agenților antifungici este implementat funcție de starea generală a pacientului, speciile fungice implicate și de confirmarea fungemiei. În concluzie, se impune un tratament specific al complicațiilor infecțioase, corect condus, pentru a reduce morbiditatea și mortalitatea și a evita dezvoltarea rezistenței microbiene.

Cuvinte cheie: arsuri grave, complicații, infecții fungice, factori de risc.

\section{INTRODUCTION}

The natural protective barriers (skin, respiratory tract and digestive tract) are usually affected in case of severe burns, getting to the the activation of the pro-inflammatory cascade that causes a complex disorder of the immune system, cumulating both cellular and humoral responses. Immune alterations determine high susceptibility for infectious complications that are a rule in the evolution of severe burns, usually marked by the presence of opportunistic germs ${ }^{1-5}$.

Fungal wound colonization and infection became progressively prevalent by introducing topical antibacterials and through empiric use of broad-spectrum antibiotics. Invasive fungal infection is correlated to higher death rates, regardless of the surface of the burn, associated inhalation burn lesions, or patient's age ${ }^{3,4}$.

Candida spp. are the most typical fungal colonizers of the burn lesion, although fungi like Aspergillus spp., Penicillium spp., Rhizopus spp., Mucor spp., Rhizomucor spp., Fusarium spp., and Curvularia spp. can also be responsible for colonization, and these may develop significant invasive potential with increased mortality ${ }^{6}$.

A correct diagnoses is often difficult, due to unspeciffic clinical symptoms which frequently imitate lowgrade bacterial infections and requirement for specific laboratory assesment. An important strategy for improving patient outcome is to prevent infectious complications ${ }^{1,3}$.

\section{METHODS}

We conducted a two year retrospective study in the Burn Unit of the Clinical Emergency Hospital Bucharest, Romania, between 01.05.2016 - 01.05.2018. Data were obtained from medical records and the hospital's eHealth program (Hipocrate), then were centralized and analyzed using Microsoft Excel. From all the hospitalized patients in our burn unit, we noted the ones who tested positive for fungi in microbiological de- terminations. Multiple parameters were evaluated for each patient: age, gender, TBSA, burn depth, presence of third degree burns, presence of inhalation injury and patient outcome.

Fungal infection types have been assessed and a dynamic fungal mapping has been established during patient hospitalization. Microbiological screening was based on patient testing at admission in the hospital and once a week or in case of clinical signs from all potential sites during hospitalization.

\section{RESULTS}

From a total of 355 patients with burn lesions, 59\% were admitted to the Critical Burn Care Unit with severe burns and $41 \%$ were treated in the Postcritical Care Unit (Figure 1).

In our two years study, from the Critical Care Burn Unit patients, we have found that 26 severely burnt patients have had positive determinations for Candida spp. and 5 patients have had present determinations for Aspergillus spp. Assessing the fungal distribution for the studied patients, we have obtained the following data: most determinations for Candida spp have been diagnosed in the first day postadmission, while most determinations for Aspergillus spp have been diagnosed seven days after the admission in the Critical Care Unit (Figure 2).

\section{Patients with identified Candida spp:}

The statistics evaluating age and sex distribution in patients with the presence of Candida Spp. revealed 9 female and 17 males with ages ranging between 23 and 88 years old, with an average of 55 years old (Figure 3 ).

In what concerns the associated pathologies in Candida burnt patients, 7 out of 26 patients had some of the following pathologies associated: HTA, Diabetes mellitus type II, COPD, VHC, stroke, obesity, depression, mental retard and chronic ethanol consume.

Regarding the evaluation of the association between 


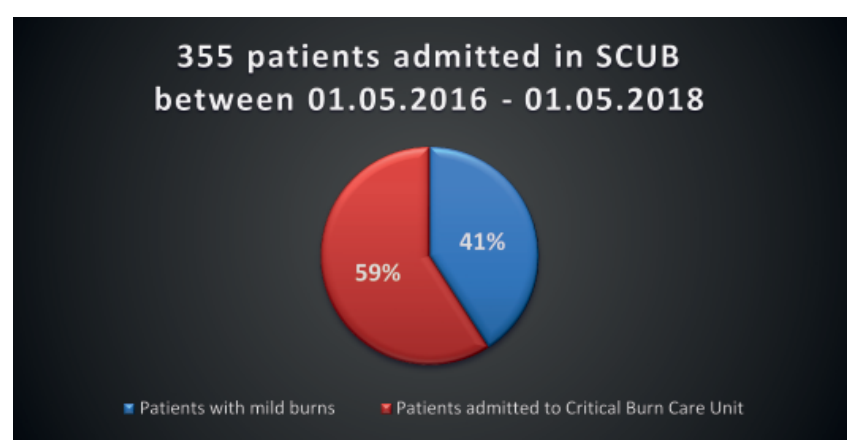

Figure 1. Distribution by burn severity for patients admitted to the "Bucharest Clinical Emergency Hospital" between 01.05.2016 01.05.2018.

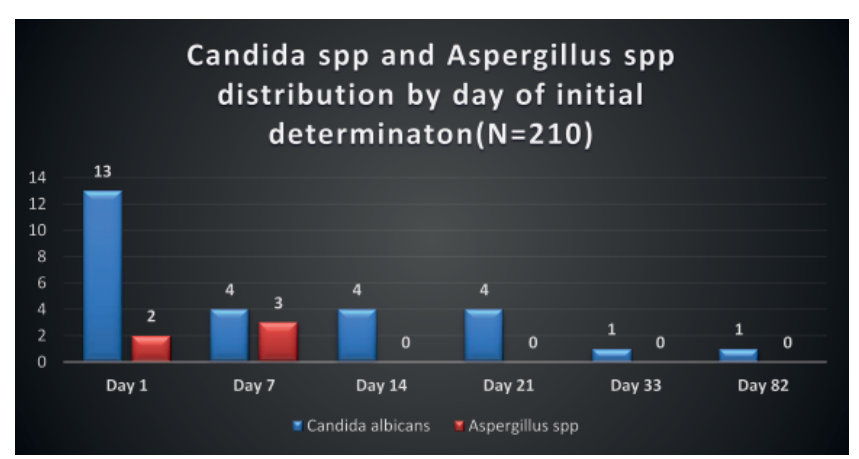

Figure 2. Fungal distribution by day of initial determination in the two year study.

the severity of the burn, a large body area with burn lesions and a high percentage of third degree burns, with Candida exposure, it has been shown that most of the patients had around 40-50\% TBSA, with an average of $47 \%$ TBSA and an average of $22 \%$ of third degree lesions (Figure 4). There have been airway burns in two of the Candida presenting patients.

Eight of the 26 patients (30.76\%) were noted as having infections with Candida spp and needed systemic antifungal therapy. The sites of infection were repre-

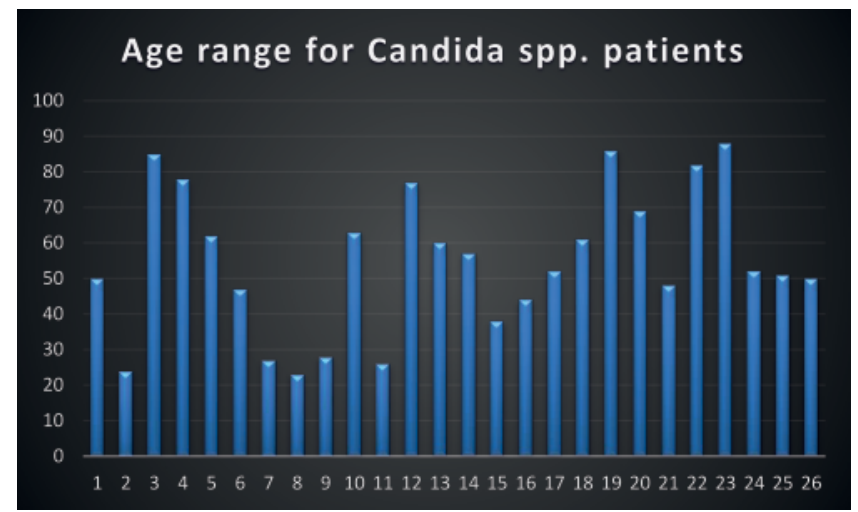

Figure 3. Distribution by age for Candida spp. patients.

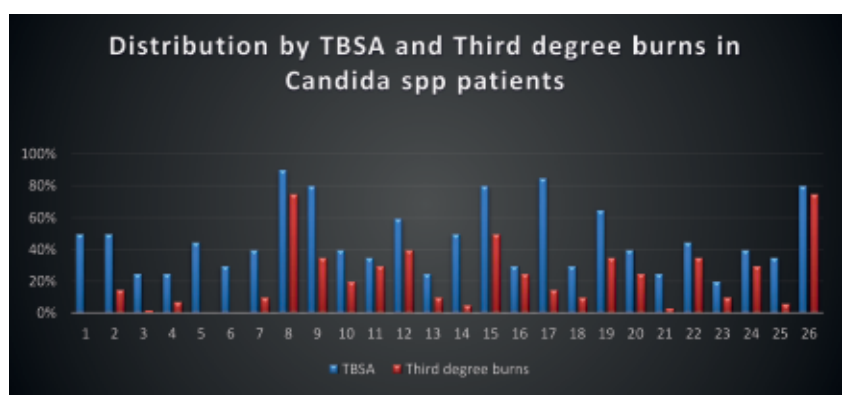

Figure 4. Characteristics of burn lesions in patients who tested positive for Candida spp.

sented by: the burn wound, respiratory, urinary and systemic; the predominant site of infection being the urinary tract (Figure 5). As revealed by antibiograms comparison, the highest sensibility of the fungi has been shown to appear when exposed to the following antifungals: Voriconazol, Fluconazol and Amphotericin B. Anidulafungin was also very effective in treatment of candidiasis in our patients. Figures 6 and 7

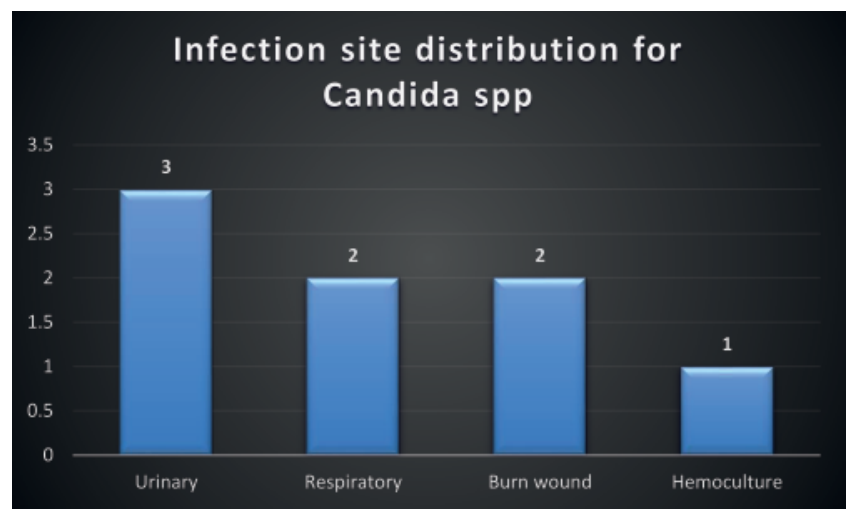

Figure 5. Distribution by infection site for the Candida spp in the two year study.

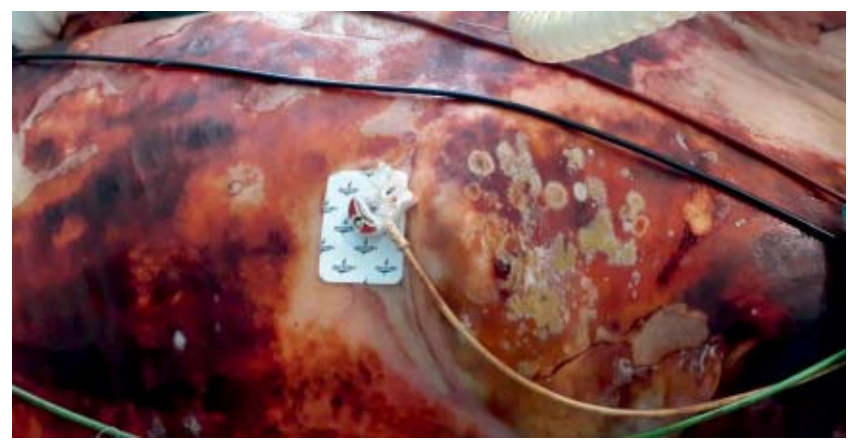

Figure 6. Candida infection in the burned wound in a 50 years old female, obese, with $80 \%$ TBSA ( $75 \%$ third degree burns) and airway burns; the patient died 9 days after the injury. 


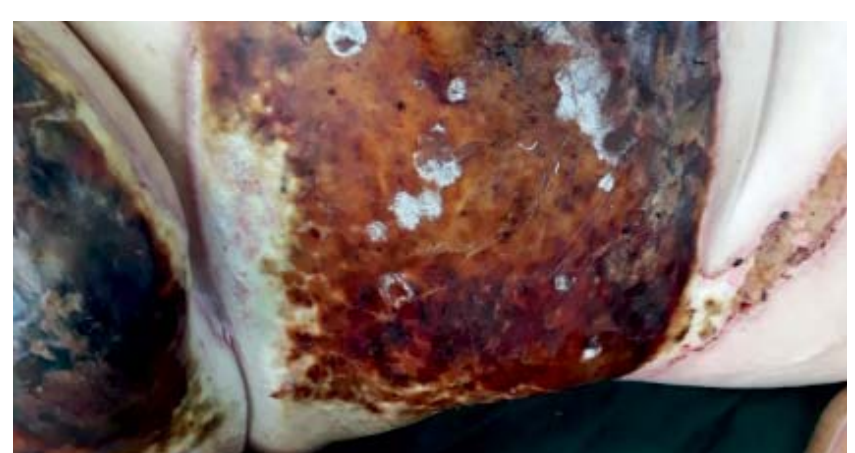

Figure 7. Candida infection in the burned wound in a 69 years old female patient with $40 \%$ TBSA $(25 \%$ third degree burns) and multiple comorbidities-obesity, diabetes, severe depressive disorder. Lesions were excised and skin-grafted, but the patient died on day 61 post-injury.

illustrates the clinical aspect of Candida presence on burned wound in two severely burnt patients.

Regarding the outcome of the patients tested positive for Candida, it results that there have been 9 patients discharged from our hospital in healing process, 16 deaths and 1 transfer to homeland for a foreign patient.

\section{Patients with identified Aspergillus spp:}

The distribution by sex and age in Aspergillus spp patients revealed a number of 4 males and 1 female with ages ranging between 48 and 59 years old, with an average of 53 years (Figure 8).

Concerning associated illnesses, hypertension, diabetes mellitus type II and chronic alcohol consumption have been associated in three patients out of five.

By assesing the distribution of TBSA and third degree burns percentage, we have reached the following results: the average TBSA was $72 \%$, third degree burns were present in an average of $45 \%$ of the burn lesions for the five Aspergillus affected burn patients. Two pa-

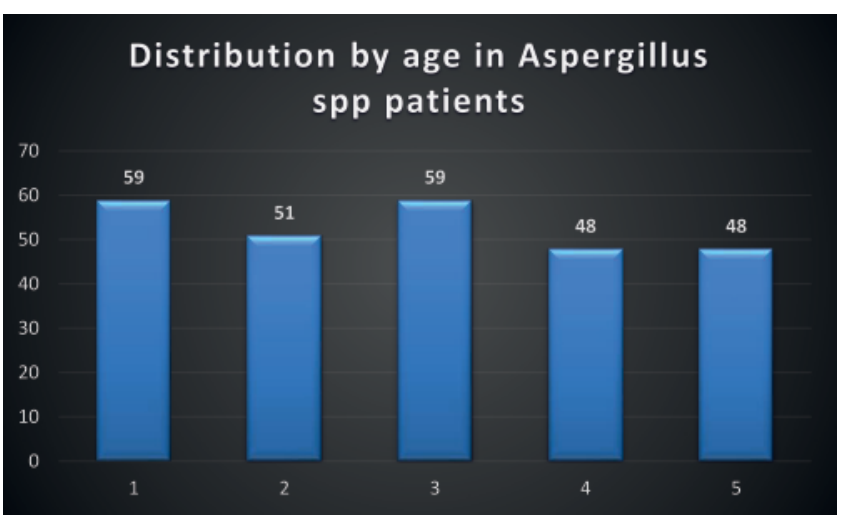

Figure 8. Distribution by age for Aspergillus spp. patients.

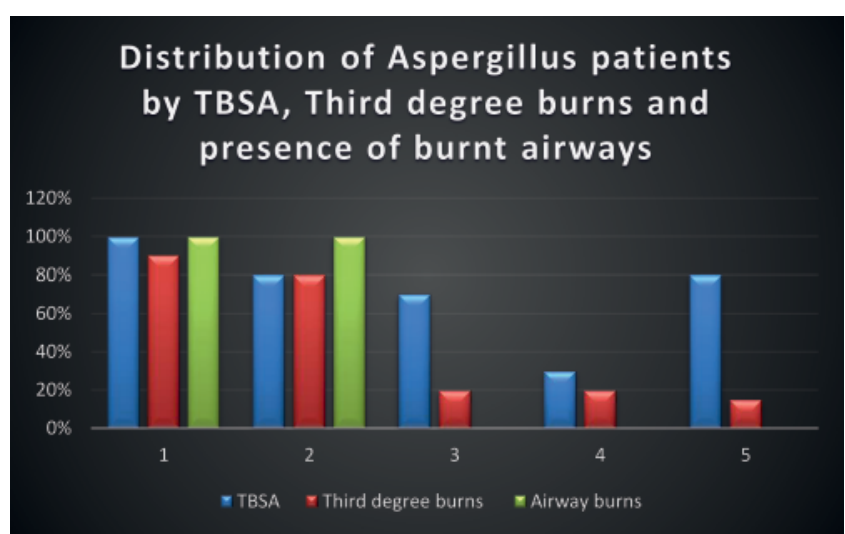

Figure 9. Characteristics of burn lesions in patients who tested positive for Aspergillus spp.

tients presented also burn lesion of the airway (Figure 9).

Aspergillus spp was detected on the burn wound in 3 patients, in ear cavity in one patient and in respiratory tract of one patient (Figure 10). All those five patients received antifungal treatment. As revealed by antibiograms, the highest sensibility of the Aspergillus has been shown to appear when exposed to the antifungal Voriconazol.

Figures 11 and 12 shows the aspect of burnt lesions tested positive for Aspergillus spp.

Regarding the evolution of Aspergillus affected burnt patients, four of the five have died and one patient was discharged from the Burn Unit in healing process.

\section{DISCUSSION}

Infections are the most common complications in our burn unit, requiring proper diagnosis and treat-

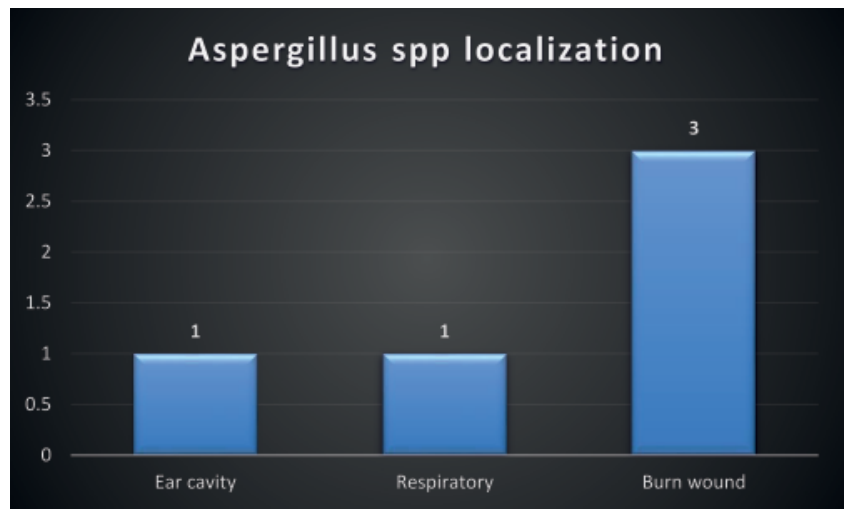

Figure 10. 

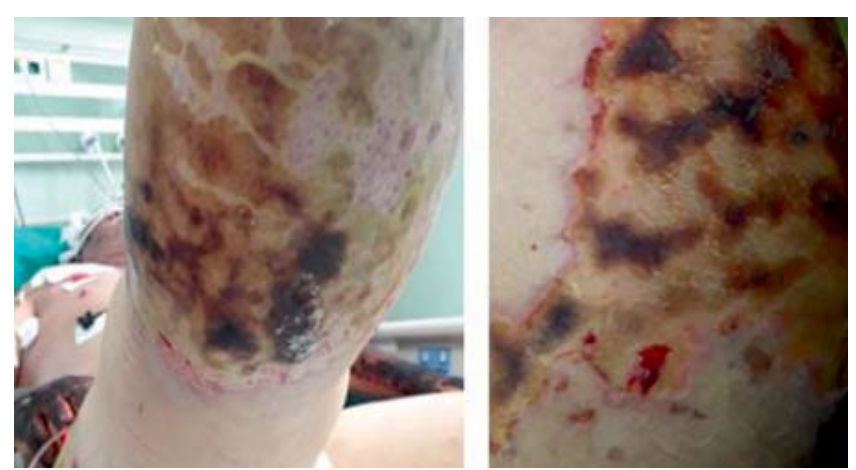

Figure 11. Aspergillus spp on the burn wound.

ment. We perform microbiological screening: at time of patient admission, than once a week or in case of clinical signs of infection from affected site and from all potential sites in undetermined sepsis. Antibiotic therapy is administered according to the antibiogram, but if necessary, when clinical and paraclinical signs are suggestive of infection, antibiotic therapy is started empirically, with a broad spectrum, and immediately after receiving the antibiogram, targeted antibiotics are administered. The principle of de-escalation is applied in order to administer the drug effective on the germ, but with a narrow spectrum and, if possible, to avoid reserve antibiotics.

An important aspect to consider is the high microbial resistance present in our country, requiring stronger antibiotics and predisposing to growth of opportunistic organisms like fungi and viruses ${ }^{2,7}$.

Diagnosis of fungal infections is difficult, with clinical alert signs which are nonspecific and not particularly different from bacterial infections, also sensitivity of diagnostic results may be inaccurate. Direct evidence of positive fungal cultures from burn sites is the main diagnostic approach but it may be correlated with latency and species-dependent diagnostic requirements $^{1,8}$. Differentiation between fungal infection and colonization in burn wounds is also very challenging.

We observed in our group that 50\% determinations for Candida spp have been diagnosed in the first day postadmission.

According to literature, previous Candida colonization is a critical risk factor for Candida presence, and the risk rises considerably along with the number of colonized sites. After burn lesions, ubiquitary Candida colonization of the skin and mucosal components of the nose, throat and digestive tract is prone to represent a latent cause of infection, particularly in patients with a deficient immune system ${ }^{1,4,9,10}$.
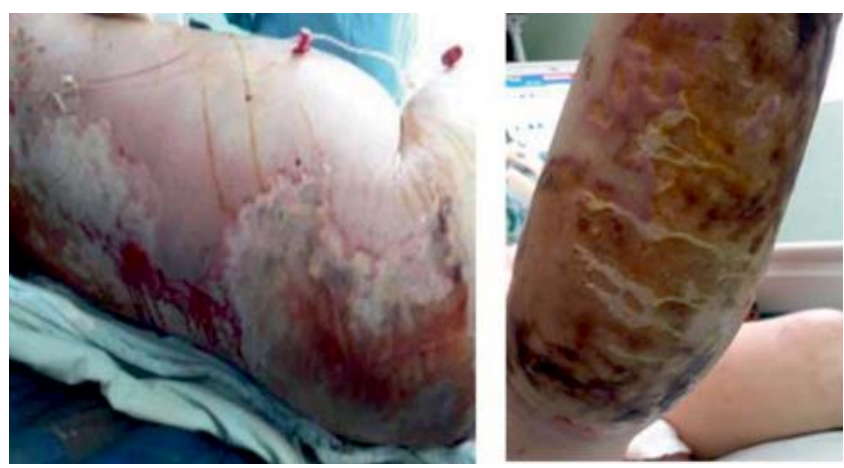

Figure 12. Aspergillus spp on the burn wound site.

Patient-specific risk factors for fungal infections after burn injury include high age groups, large burns $>40 \%$ burned TBSA and inhalation lesions. Additional contributing elements are neutropenia, uncontrolled Diabetes mellitus and the need for central venous catheters ${ }^{1,11}$.

Patients tested positive for fungi in our group were around the sixth decade of life and presented predominantly extensive burns, over 40\% TBSA and full thickness burns, characteristics well known as negative prognostic factors leading to increased morbidity and mortality ${ }^{12,13}$.

Ten patients out of 31 (one third) in which we identified fungi, presented significant comorbidities which altered their survival prognosis.

The most critical target in burn patients that have a high infection risk is a quick achievement of adequate immune competence. This objective may be facilitated by prompt enteral nutrition, precocious and entire burn wound excision and grafting, restrictive utilization of blood transfusion, early detachment from mechanical ventilation, restraint from broad spectrum antibiotic prophylaxis, targeted antibiotic therapy, recurrent reevaluation, as well as limited utilization of invasive catheterization if possible ${ }^{1}$.

Specific treatment includes topical antifungal agents and systemic treatment in severe cases. For burn wound site fungal localization, topical treatment may be applied and efforts to obtain burn wound closure as fast as possible are made, but if invasive infection is considered, systemic antifungals are then administered as first line treatment. The systemic administration of antifungals is conditioned by the general status of the burned patient, the type of fungus involved and the laboratory clear diagnostic for mycosis or confirmation of fungemia. The antifungal agent is selected according with the appropriate antimicrobial susceptibility. Invasive 
fungal infections of the burn wounds require prompt, extensive, surgical debridement, even limb amputation if necessary to obtain local infectious control ${ }^{1,14}$. After efficient control of wound infection( negative cultures must be obtained) and there is no evidence for sepsis with fungi, definitive coverage of the burn area must be performed as soon as possible using skin grafts or skin substitutes ${ }^{5}$.

As important principle, infection control protocols are mandatory in a burn unit and must be carefully respected, microbiological surveillance is useful in determine the characteristics of local flora, as fungal infections are difficult to identify and the treatment is specific and expensive ${ }^{5}$.

\section{CONCLUSIONS}

Fungal infections in burns are prone to appear in patients with large burn surfaces, deficient immune system, advanced age and irrational use of broad-spectrum antibiotic therapy.

\section{References}

1. Struck MF, Gille J. Fungal infections in burns: a comprehensive review. Annals of Burns and Fire Disasters. 2013 Sep;26(3):147153.

2. Whitaker IS (Editor), Shokrollahi K (Editor), Dickson WA (Editor), Burns (Oxford Specialist Handbooks in Surgery), Oxford University Press, 2019

3. Norbury W, Herndon DN, Tanksley J, Jeschke MG, Finnerty CC. Infection in Burns. Surg Infect (Larchmt). 2016;17(2):250-255.

4. Church D, Elsayed S, Reid O, Winston B, Lindsay R. Burn wound infections. Clin Microbiol Rev. 2006;19(2):403-434.

5. Capoor MR, Sarabahi S, Tiwari VK, Narayanan RP. Fungal infections in burns: Diagnosis and management. Indian J Plast Surg 2010;43(Suppl):S37-S42.

6. Gallagher JJ,Branski LK, Williams-Bouyer N, Villareal C, Herndon DN, Treatment of infection in burns, chapter in Herndon DN(Editor), Total Burn Care - Fifth Edition, Saunders Elsevier, 2012

7. Surveillance of antimicrobial resistance in Europe 2018, European Centre for Disease Prevention and Control, available on https://www.ecdc.europa.eu/
Regarding the mycoses clinical therapy, it is mandatory to dissociate between fungal colonization and fungal infection. Unfortunately, frequently in the case of a burn patient, the presence of clinical signs is nonspecific and the sensibility of the diagnostic results is variable.

The systemic support of the patient allowing recovery of immune competence and adequate early surgical excision of burn eschar and coverage of the defects, are key factors in reducing the risk determined by fungal infections in major burns.

Compliance with ethics requirements: The authors declare no conflict of interest regarding this article. The authors declare that all the procedures and experiments of this study respect the ethical standards in the Helsinki Declaration of 1975, as revised in 2008(5), as well as the national law. Informed consent was obtained from all the patients included in the study.

8. Rodloff C, Koch D, Schaumann R: Epidemiology and antifungal resistance in invasive candidiasis. Eur J Med Res, 28: 187-95, 2011.

9. Moore EC, Padiglione AA, Wasiak J et al.: Candida in burns: risk factors and outcomes. J Burn Care Res, 31: 257-63, 2010.

10. Branski LK, Al-Mousawi A, Rivero H et al.: Emerging infections in burns. Surg Infect, 10: 389-97, 2009

11. Gore DC, Chinkes D, Heggers J et al.: Association of hyperglycemia with increased mortality after severe burn injury. J Trauma 51: 540-4, 2001.

12. Jeschke $M G$, Pinto $R$, Kraft $R$, et al. Morbidity and survival probability in burn patients in modern burn care. Critical care medicine. 2015;43(4):808-815.

13. Lundgren RS, Kramer CB, Rivara FP, et al. Influence of Comorbidities and Age on Outcome Following Burn Injury in Older Adults. Journal of burn care \& research : official publication of the American Burn Association. 2009;30(2):307-314.

14. Luo G, Tan J, Peng Y, et al. Guideline for diagnosis, prophylaxis and treatment of invasive fungal infection post burn injury in China 2013. Burns Trauma. 2014;2(2):45-52. 